\section{Cross Channel Consumer Behavior and its Benefits: Scale Validation to Assess Purchasing Process Performance}

\author{
Rafael Barreiros Porto ${ }^{1}$ \\ Sionara Ioco Okada ${ }^{1}$ \\ ${ }^{1}$ University of Brasilia, Postgraduate Program in Business, Brasilia, Brazil
}

Received on

08/01/2017

Approved on

03/05/2018

Responsible editor:

Prof. Dr. Guilherme Shiraishi

Evaluation process:

Double Blind Review

\begin{abstract}
Purpose - This paper developed and validated a scale of cross-channel behavior and its benefits capable of ascertaining the performance of the consumer buying process.
\end{abstract}

Design/methodology/approach - The sample of 451 consumers filled out questionnaires for statistical validation purposes. Three first order reflective $\mathrm{CCB}$ constructs and four $\mathrm{CCB}$ benefits were tested with second and third order formative models

Findings - The validation indicated that all constructs have convergent and discriminant validity. CCB is formed by simultaneous information searches, product/price comparisons, and interactions with the retailers/manufacturers, and the benefits are symbolic/ utilitarian and positive/negative. The coefficient between CCB and its benefits is considerable, with the avoidance of purchasing process problems being an expected result.

Originality/value - The article highlights the conceptual construction of the cross channels consumer behavior construct as generating improvements in buying process performance. Marketing researchers can test the frequency of this new behavior in consumer relations.

Keywords - Cross channel; Psychometric scale; Statistical validation; Consumer behavior; Consumer performance.

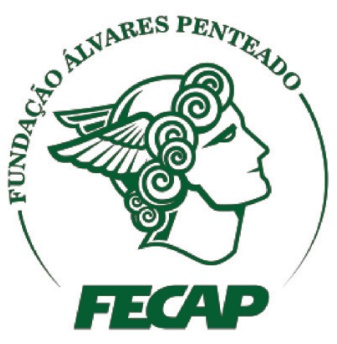

Review of Business Management

DOI: $10.7819 /$ rbgn.v20i3.3415 


\section{Introduction}

The existence of multiple purchasing channels is transforming the whole retail chain, most notably due to changes in consumer behavior. Standing out among these changes is the increase in Cross Channel Behavior - CCB - which refers to alternating between online and offline channels in a given purchasing process (Gensler, Verhoef, \& Böhm, 2012; Gerritsen et.al., 2014). In this environment, one factor that contributes to the increase in this behavior is the expansion of consumer mobility, resulting from the ownership and use of mobile devices. This mobility has incentivized the simultaneous use of online and offline channels, leading to an increase in the use of search engines, an increase in price comparison websites, and enabling more sales conversions (Saad, 2013).

In the academic sphere, a wide range of theoretical or empirical studies on behaviors tangent to $\mathrm{CCB}$ have taken center stage in the last decade: the role of multichannel retail (Neslin \& Shankar, 2009; Pauwels, Leeflang, Teerling, \& Huizingh, 2011); Cross Channel strategies (Gerritsen et al., 2014; Trenz, 2015); the Omnichannel evolutionary concept (Frazer \& Stiehler, 2014; Rigby, 2011; Valentini, Montaguti, $\&$ Neslin, 2011); and the adoption and spread of technology in retail (Bell, Choi, \& Lodish, 2012).

Although recent studies have shown the relevance of purchasing process behavior in multiple online and offline channels (Flavián, Gurrea, \& Orús, 2016; Gerritsen et. al., 2014; Trenz, 2015), there are few academic papers that have systematically developed a specific instrument for measuring CCB and its benefits for the consumer (Gerritsen et al., 2014; Trenz, 2015). The representation of this behavior using psychometric techniques can provide precision and standardization (Pasquali, 2007) for the purposes of understanding conduct that is ever more common in consumers: the adoption of new technologies for product and service purchasing processes coexisting with pre-existing technologies for the same end (Xu, Venkatesh, Tam, \&
Hong, 2010). However, a broader vision of the dimensions that compose $\mathrm{CCB}$ and the possible benefits of its adoption are spread throughout the literature. In addition, a theoretical model that contextualizes them is useful for explaining the possible result derived from research on its use.

This study aimed to develop and validate a scale of adoption of Cross Channel Behavior and its utilitarian/symbolic benefits combined with programmed positive/negative consequences to be delivered to the consumer. The use of this scale can detect the purchasing process performance generated by the frequency of adoption of CCB.

\section{Cross Channel Behavior (CCB)}

Some preliminary classification proposals have inserted CCB into the procedural stages of pre-purchase and effective purchase of a product, for example searching for product information in the online channel and carrying out the purchase in the offline channel (Gerritsen et. al., 2014; Zang, 2012). This occurs for various reasons, such as different pricing between the online and offline channels, the need to manipulate and try the product before choosing, the urgency with which the product is needed, and the unreliability concerning purchases made over the internet (Aghekyan-Simonian, Forsythe, Kwon, \& Chattaraman, 2012; Trenz, 2015; Zhou \& Piramuthu, 2010).

Bramall, Schoefer, and McKechnie (2004) had already observed evidence of internet use (online channel) solely to obtain information about products, with purchases occurring in the physical store (offline channel). However, the authors also observed the opposite and reported evidence of purchases carried out solely in the physical channel due to specificities of the product that made it difficult to sell through the online channel. Other studies have observed the completion of purchases in the channel that offers the lowest price, which often occurs in the online channel, despite shipping (Aghekyan-Simonian et al., 2012; Ling, Daud, Piew, Keoy, \& Hassan, 2011; Lu \& Su, 2009; Zang, 2012). In addition, 
Kim and Kim (2006) had already observed that the interaction between consumer and retailer/ manufacturer extends to the post-purchase stage and can use both channels, since the consumer can pay in the physical store and monitor the status of the order online, whether tracking the delivery of the product or using Customer Services for suggestions and/or complaints.

Thus, the purchasing behavioral process in crossed channels is broad, numerous, and multidimensional. By combining the pieces, dimensions can be listed, including simultaneous information searches regarding products, product/ price comparisons, and consumer interaction with the retailer/manufacturer, which can occur during the whole purchasing process, starting from prepurchase and extending to post-purchase.

In a behavioral chain, simultaneous searches for information about products, product/price comparisons, and interactions with retailers/manufacturers can be considered as auxiliary precurrent behaviors not required by the purchasing situation (Oliveira-Castro \& Campos, 2004; Pohl \& Oliveira-Castro, 2008), since the consumer can in principle buy (current behavior) without any information search (precurrent behavior), buy without comparing products/ prices (precurrent behavior), and not interact with the retailer/manufacturer (precurrent behavior) in a given purchasing process. However, purchases are unlikely to occur without the consumer ever having carried out any of these precurrent behaviors. Precurrent behaviors are defined as responses that increase the frequency of other responses occurring, these being called current (e.g. the purchase of the product), or being reinforced (Oliveira-Castro, Faria, Dias, $\&$ Coelho, 2002). In this conception, CCB becomes a personal strategy to improve the achievement of a response (e.g. purchase) and/or the benefits related to the acquisition process. Consumers who adopt this behavior try to acquire the means to purchase more quickly, acquire better quality products, spend less financial resources and time, avoid the physical effort of displacement, minimize third party criticism, or maximize compliments from reference groups. In other words, it can lead to better performance in their purchases.

\section{I The simultaneous search for information (about products)}

Searching for information about products can be an important consumer experience for generating pleasure derived from cognitive curiosity, as well as being able to improve consumer choices (Shin, 2009). Moon (2004) already indicated that in the decision-making process, the consumer can obtain information that is able to ensure better quality products and advantages in terms of price and range, and that can save time and increase convenience.

In addition, studies that have investigated consumption in the online channel have already indicated that the fun and entertainment in searching for products or in comparing products/ prices over the internet can generate a multisensorial experience in the process of purchasing products or services (Bridges \& Flossheim, 2008; Hirschman \& Holbrook, 1982; Overby \& Lee, 2006), with or without the purchase actually being made.

Many researchers have studied the hedonistic behavior of searching for product information, which can be explained by a number of reasons: i) a pleasurable sensation derived from the imaginary use of products and objects seen and desired in stores and window displays (Campbell, 2001), ii) entertainment (Bridges \& Florsheim, 2008), iii) the establishment of social and family bonds and ties (Raghunathan \& Corfman, 2006), iv) the search for self-gratification, which refers to the pleasure and contentment derived from carrying out purchase experiences as a way of improving a momentary negative emotional state, whether as a form of distraction or to improve self esteem (Arnold \& Reynolds, 2003); v) following market tendencies and innovations (Gursoy, Spangenberg, \& Rutherford, 2006); vi) voyeurism, to contemplate people, products, environments, and objects (Holbrook, 2001). 
From the $\mathrm{CCB}$ perspective, the search for information occurs simultaneously via the internet and in physical stores. It can be linked or not to the purchase actually being carried out (Ling et al., 2011), but it can also be linked to the way products are acquired (Moon, 2004). Consumers can search for product information in physical stores (offline channel) without the intention to acquire ( $\mathrm{O}^{\prime}$ 'Shaughnessy \& O'Shaughnessy, 2007), look at window displays simply out of cognitive curiosity (Cheong \& Park, 2005) or for fun or leisure (Kiseol, 2010), but they can also improve the quality of how they buy and what they buy, optimizing resources and time as a result of the information acquired (Moon, 2004).

\subsection{Comparing products and prices}

When comparing products and prices the consumer seeks to measure the price of alternative brands or promotional prices, payment of the purchase in installments, or discounts in any store where the product is sold (Srivastava \& Chakravarti, 2011). However, individuals are not able to identify all the price possibilities of all products in all stores. There are obstacles to individuals when comparing, such as: time and cost constraints in the search and limitations in terms of intellectual capacity, perception, and the retention of information (Nagle, Hogan, \& Zale, 2011).

The ease of buying products/services due to the democratization of the use of search engines and price comparison websites (Buscapé, Bondfaro, Zoom.com) on the internet has been influenced by the popularization of the use of mobile devices (Bell et al., 2012). This discussion relates to the proposition that the choice of product composition tends to differ between the online and offline channels, since different pricings can result in comparatively different evaluations between consumers in different stores.

The behavior of comparing products/ prices even enables different physical stores to be compared online by consulting the location of stores, whether they are open or closed etc. From this perspective, the act of comparing products/ prices by simultaneously using online and offline channels has weight in the purchasing process, since it precedes the acquisition and use of the product.

\subsection{Interaction with the retailer/ manufacturer}

The form of interaction between consumers and retailers/manufacturers differs between the online and offline channels, since the mode of communication, convenience of access to the company, and interactive technologies also differ from one channel to another (Trenz, 2015). This interaction can be defined as communicative activities that aim to obtain confidence in the transaction or maintain a beneficial relationship and refund losses. This interaction aims to maintain a relationship of value (cost/benefit) and tools of communication are necessary conditions for the occurrence of this phenomenon (Currás-Pérez \& Sánches-García, 2012). In general terms, these interactions initiated by the consumer can generate performance gains via the consequences generated (Dias \& Oliveira-Castro, 2006), minimizing losses and/or obtaining gains of some kind.

The interaction with the retailer/ manufacturer can occur at any stage of the purchasing process. Bhatnagar and Ghose (2004) indicated some attributes considered by consumers before or after making a purchase in the online channel: determining the retailer's reputation, obtaining quality information about products, carrying out refunds, requests, or order cancellations, monitoring the delivery of orders, etc. Customer Services can be useful for these purposes (Filomeno, 2011) and can generate damage reparation (Giordano, 1996), which is a consequence with the potential to improve the balance of commercial relations.

However, consumers' demands or complaints may be easier to adopt or check in one buying channel than in another due to the configuration of the retail service. Some demands are easier to execute online (e.g. checking 
reputation and monitoring an order), while others (e.g. obtaining a refund) are generally more immediate in the offline channel.

\section{The Benefits of Consumers Adopting CCB}

By adopting CCB, benefits can be generated for the agent who executed it. Executing auxiliary precurrent behaviors (Oliveira-Castro, 2003) can make the purchasing process more efficient, reducing search time, choosing products that provide the best cost/benefit relationship, accelerating or postponing the purchase to a suitable time, etc. That is, CCB can improve consumer performance.

These benefits, or reinforcers in the terms of Skinner (1969), can be positive or negative. After the execution of a behavior, the positive benefits (reinforcers) are consequent stimuli added to the environment (e.g. making the product available at more sales points, thus generating convenience, or adding an attribute to the product, thus generating greater quality), which increases the frequency of emission of the same behavior in future situations. As for the negative benefits (reinforcers), these are consequent stimuli removed from the environment (e.g. suppression, postponement, or cancellation of an adverse stimulus such as payment of the merchandise), which increases the frequency of emission of the same behavior in future situations. These negative reinforcers are generally presented in the form of avoidance of or escape from a situation that is undesired by the individual, thus avoiding risks (Moreira \& Medeiros, 2009). The difference between the positive (gains) and negative (avoidance of loss) benefits has been pointed out by a number of authors (Magoon, Critchfield, Merrill, Newland, \& Schneider, 2017; Nevin \& Mandell, 2017).

Any benefit to the consumer, whether positive or negative, can be utilitarian and/or symbolic (Foxall, 2010). Utilitarian benefits are those mediated by the acquisition process and use of the product, when for example the consumer buys some washing power again because it was effective in removing a stain on his/her clothes. Symbolic benefits are mediated by social environments, such as buying a good due to a suggestion from some family member. These utilitarian and symbolic benefits can combine with positive and negative benefits, thus forming a 2 x 2 combination matrix.

Positive utilitarian benefits resulting from $\mathrm{CCB}$ refer to consequences mediated by the acquisition process and use of a product, which increases the probability of this auxiliary precurrent behavior occurring again, after the insertion of a favorable stimulus. For example, a consumer may search for information on the various configurations or variety of options for a product on websites before heading to a physical store to make the purchase. This search improves the process of acquiring better quality products. Finding the best quality product or discovering a greater variety of the same product are consequences of this behavior, since one retailer, in the role of environment for the consumer (Foxall, 2010), may add an offer of better quality products than another retailer.

In contrast, negative utilitarian benefits refer to a consequence mediated by the acquisition process and use of the product that increases the probability of this auxiliary precurrent behavior occurring again, after the removal of an unfavorable (aversive) event (Foxall, 1998, 2005). This can cover the avoidance of delays in delivering the product, saving resources, and postponement of payment. One example of this case would be the consumer obtaining benefits from making a purchase in the online channel with free shipping (removal of shipping payment) or with the removal of interest, since these are aversive events for the consumer. Thus, the avoidance of risks (or avoidance of loss) can equally improve consumer behavior.

Symbolic benefits are social and mediated by other people (Foxall, 1998) and can be positive and negative. Positive symbolic benefits refer to a social consequence that increases the probability 
of the precurrent behavior occurring again, after the insertion of an event that results in positive feedback about the consumer's performance (Foxall, 2010; Pohl \& Oliveira-Castro, 2008). For example, a consumer and his family are in a physical store to buy a product. If he uses the internet on his mobile device to compare prices of this product in the online channel, he may find the same product cheaper in another virtual store and can carry out the acquisition in the online channel. His family, in turn, approves of and praises the search behavior of this consumer. This social approval from close ones, via praise and positive recommendations, is a social stimulus that is present in the purchasing situation and can influence the new occurrence of the same behavior due to the better performance generated.

Negative symbolic benefits, in turn, refer to social consequences that increase the probability of the auxiliary precurrent behavior occurring again, after the removal of an event that results in unfavorable (aversive) feedback about the consumer's performance (Foxall, 1998). This is generally perceived as the avoidance of some social embarrassment. For example, a consumer may have been criticized by a friend for a low quality product bought previously. So, he searches for information about the reputation and honesty of the retailer/manufacturer on complaints sites (e.g. Reclame aqui) before carrying out the next purchase in the physical store. This careful consumer behavior results in his reference group (family and friends) ceasing to criticize him.

\section{Theoretical Model}

The theoretical model proposed in this study was inspired by the BPM (Behavioral Perspective Model) model from Foxall (1998), considering that the main causes of consumer behavior are located in the situation that involves the purchasing process. Foxall (2010) argues that there are discriminatory or adverse stimuli composing the purchasing scenario and that interact with the consumer's learning history to predict a consumer behavior. In addition, this stimulus/response relationship generates consequences, such as the beneficial or harmful ones (utilitarian and symbolic).

Adaptations to the BPM model were made to contextualize this study. The first of them relates to the behavior itself. As CCB is an auxiliary precurrent behavior, its adoption relates to a set of virtual and real responses that assist acquisition. In this sense it is not a final behavior in a behavioral chain of consumption, but rather an intermediate one. The multidimensionality of CCB contemplated in this study has three latent dimensions: i) the simultaneous search for information about a product; ii) product/price comparison; and iii) the interaction with the retailer/manufacturer. These dimensions form the CCB construct; that is, CCB is formed of the combination of these three dimensions and not the cause of them. This warrants the structuring of the second order CCB construct being formative and not reflexive (Henseler, Hubona, \& Ray, 2016).

The second adaptation refers to the consequences. The consequence of a precurrent behavior is a current behavior (end of the chain), but in this paper the consequence will only be addressed by the benefits aspect, such as gains or the avoidance of losses in the purchasing process. Thus, these benefits occur over the course of the behavioral sequence, improving the purchasing process itself. The obtainment of these thus characterizes reinforcements derived from the purchasing process. This study calls them CCB Benefits (third order construct), and they are formed of Utilitarian Benefits and Symbolic Benefits (second order). As both have different content, they form the third order construct, called the formative (and not reflexive) relationship.

In addition, the first order constructs (Positive Utilitarian Benefit and Negative Utilitarian Benefit) have different content from each other (gains and avoidance of loss mediated by the product purchasing process, respectively), and together they form the second order construct 
Utilitarian Benefit. As for the first order constructs (Positive Symbolic Benefit and Negative Symbolic Benefit), they also have different content from each other (gains and avoidance of loss, mediated by the social environment of the purchasing process, respectively), and together they form the second order construct Symbolic Benefit.

The composites model in this study (Figure 1) was constructed in the format suggested by Van
Riel, Henseler, Kemény, and Sasovova (2017). Its formation is more consistent for explaining the differences in content between the constructs. It more faithfully illustrates the empirical test, avoiding redundant mistaken interpretations between constructs that form hierarchical structures - the problem of incorrect specification of the measurement model (Diamantopoulos, Riefler, \& Roth, 2008).

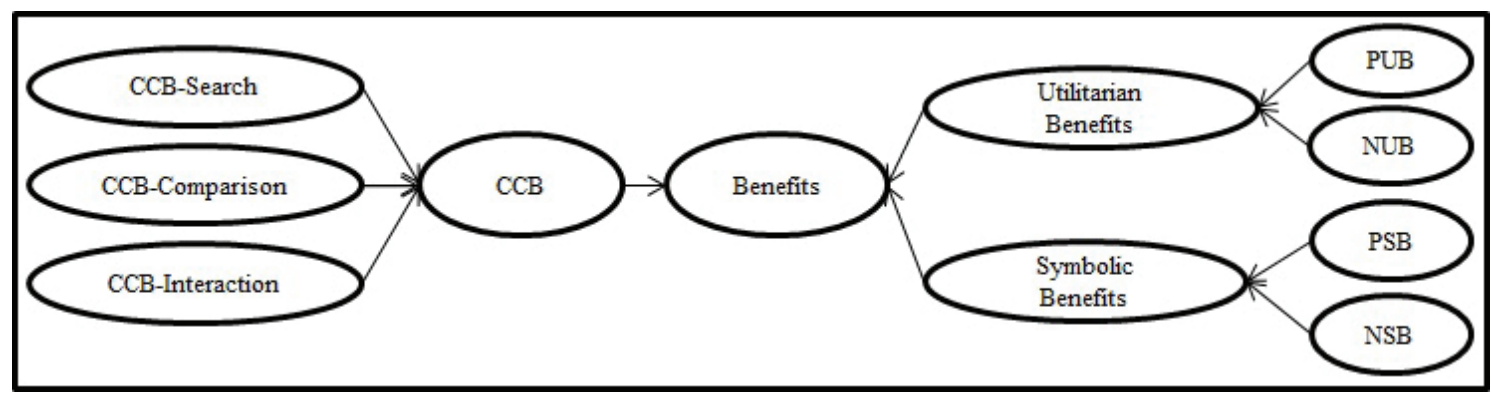

Figure 1. Conceptual research model.

Key: CCB-Comparison (product/price comparison), CCB-Search (simultaneous information search), CCB-Interaction (interaction with the retailer/manufacturer), Benefits (benefits of CCB), Symbolic Benefits (symbolic benefits of CCB), Utilitarian Benefits (utilitarian benefits of CCB), PSB (positive symbolic benefits of CCB), NSB (negative symbolic benefits of CCB), PUB (positive utilitarian benefits of CCB), NUB (negative utilitarian benefits of CCB).

Source: Elaborated by the authors.

\section{Method}

This study is explanatory and crosssectional, since the aim was to explain the nature of the relationships between variables by verifying a hypothetical causal model between consumers. The scale validation proposed occurred in two stages: the first relates to the judgment of the semantic content carried out by expert evaluators (Pasquali 2007), who determined whether the scale measured a representative sample of all the purchasing procedural behaviors related to cross channels and their benefits. The scale creation and development stage was necessary due to the absence of measuring instruments that contemplated CCB and its benefits of adoption. The second stage occurred at the statistical level with factor analyses and convergent validity, discriminant, and reliability tests (Byrne, 2010;
Hair, Black, Babin, \& Anderson, 2010). Then the path analysis of the structural model was carried out.

\section{I Sample}

The total sample obtained totaled 451 respondents, $52.8 \%$ of which were female. Regarding the other social demographical factors, around $75 \%$ of the respondents stated that they were in the 25-29 age group and more than half of the respondents $(53.5 \%)$ stated that they were in the 1-5 minimum wages income band. A significant number of respondents $(72.5 \%)$ stated that they had two or three mobile devices (laptops, smart phones, and tablets).

The Hoelter critical (minimum) sample (0.01) was in the order of 224. The sample of 451 was shown to be more than sufficient to carry out the Confirmatory Factor Analysis. The sampling 
power for the Confirmatory Factor Analysis with 179 degrees of freedom and an alpha of 0.01 and null hypothesis RMSEA in the order of 0.08 was equal to $99.7 \%$, which is sufficient enough to reduce the chances of occurrence of a Type 2 Error, or false negative.

\subsection{Development of the Instrument}

The elaboration stage of the semantic scale of CCB content and its benefits was necessary to support the creation of items in the questionnaire format and its correspondence to the proposed latent constructs. The steps proposed by Devellis (2011) and Pasquali (2007) were followed. So, initially, a set of 15 (pre-scale) CCB items and 18 (pre-scale) CCB benefit items was created based on the literature review, in which eleven criteria proposed by Pasquali (2007) were adopted.

The semantic validation of the proposed scale was carried out by expert evaluators $-\mathrm{PhDs}$ in Behavioral Science and researchers in consumer behavior and also three consumers with more than 10 years' experience in purchases using multichannels, including the digital one. The judges determined whether the items developed belonged to the constitutive definition of the proposed constructs and whether the scale measured a representative sample involving the CCB constructs and those for its benefits (De Vellis, 2011). They were evaluated and only considered adequate if there was a minimum agreement of $80 \%$ of the judges with regard to the classification into categories and factors.

As a result of this phase, some items were eliminated from both scales and the redactions and wording of some of them were altered. In the final version, the set of 9 sentences for CCB used a 5 -point scale of frequency $(1=$ never; 2 = rarely; 3 = sometimes; 4 = often; 5 = always) to determine the adoption of the alternating use of online and offline channels in a purchasing process.

In the final version of the CCB Benefits scale, the set of 12 sentences were laid out in a 5 -point scale of agreement $(1=$ totally disagree to 5 = totally agree) to determine the perception of the benefits. The set of items, with the confirmatory validation of 9 items for $\mathrm{CCB}$ and of 12 items for benefits, can be seen in Table 1, with their measures and standard deviation.

Table 1

\section{Wording of the CCB and benefits scales, items, and descriptive analysis}

Wording of the CCB: Mark the frequency of your behavior concerning the process of purchasing a product $\mathrm{X}$ using the online and offline channels.

\begin{tabular}{|c|c|c|c|}
\hline Latent Constructs & Items & Mean & $\begin{array}{l}\text { Standard } \\
\text { Deviation }\end{array}$ \\
\hline \multirow{3}{*}{$\begin{array}{l}\text { CCB: product/price } \\
\text { Comparison }\end{array}$} & $\begin{array}{l}\text { CCB1 - I use my smartphone, tablet, or laptop to compare product } \\
\text { prices before buying in the physical store. }\end{array}$ & 3.93 & 1.03 \\
\hline & $\begin{array}{l}\text { CCB2 - When I am in a physical store to buy a product, I use my smartphone or } \\
\text { tablet in order to compare prices of the same product in other stores. }\end{array}$ & 3.08 & 1.28 \\
\hline & $\begin{array}{l}\text { CCB3 - I use cell phone and/or tablet applications to compare where the closest } \\
\text { physical store is to purchase products. }\end{array}$ & 3.50 & 1.15 \\
\hline \multirow{3}{*}{$\begin{array}{l}\text { CCB: simultaneous } \\
\text { information Search }\end{array}$} & $\begin{array}{l}\text { CCB4 - At the same time as I am buying in the physical store, I am } \\
\text { online (with my cell phone or tablet) searching for the same product on } \\
\text { the internet. }\end{array}$ & 3.17 & 1.23 \\
\hline & $\begin{array}{l}\text { CCB5 - I see a promotional offer in a physical store and at the same time I search } \\
\text { for promotions on the internet (via cell phone/tablet). }\end{array}$ & 3.63 & 0.97 \\
\hline & $\begin{array}{l}\text { CCB6 - While I am in the physical store, I use applications for cell phones and/or } \\
\text { tablets to obtain additional information about the products. }\end{array}$ & 3.20 & 1.19 \\
\hline
\end{tabular}




\begin{tabular}{|c|c|c|c|}
\hline \multirow{3}{*}{$\begin{array}{l}\text { CCB: Interaction with } \\
\text { the retailer/manufacturer }\end{array}$} & $\begin{array}{l}\text { CCB7 - Before making the purchase in the physical store, I search the } \\
\text { internet for information about the reputation of the manufacturer/ } \\
\text { vendor. }\end{array}$ & 3.72 & 1.17 \\
\hline & $\begin{array}{l}\text { CCB8 - I use the internet to make suggestions and/or complaints (customer } \\
\text { services) about a purchase made in the physical store. }\end{array}$ & 3.40 & 1.19 \\
\hline & $\begin{array}{l}\text { CCB9 - After paying for a product in the physical store, I monitor and track my } \\
\text { order on the internet using mobile devices (cell phone, tablet, laptop). }\end{array}$ & 3.79 & 1.22 \\
\hline \multicolumn{4}{|c|}{$\begin{array}{l}\text { Wording of the benefits: If I use the internet (online channel) and the physical store (offline channel) alternately in a purchasing } \\
\text { process, I will probably be able to: }\end{array}$} \\
\hline \multirow{3}{*}{$\begin{array}{l}\text { PUB } \\
\text { (Positive utilitarian } \\
\text { benefit) }\end{array}$} & PUB1 - Verify the availability of products/services that I wish to acquire. & 4.42 & 0.73 \\
\hline & PUB2 - Acquire better quality products/services. & 4.24 & 0.78 \\
\hline & PUB3 - Obtain a greater variety of choice of products/services. & 4.37 & 0.69 \\
\hline \multirow{3}{*}{$\begin{array}{l}\text { NUB } \\
\text { (Negative utilitarian } \\
\text { benefit) }\end{array}$} & $\begin{array}{l}\text { NUB1 - Find the safest way to pay (in cash, in installments, bank payment slip, } \\
\text { credit card, among others). }\end{array}$ & 4.29 & 0.87 \\
\hline & $\begin{array}{l}\text { NUB } 2 \text { - Save my time and resources (avoiding queues, avoiding waiting in } \\
\text { traffic, among others). }\end{array}$ & 4.36 & 0.78 \\
\hline & $\begin{array}{l}\text { NUB } 3 \text { - Avoid delays in the delivery of the products or delays in the provision of } \\
\text { the services. }\end{array}$ & 4.03 & 0.93 \\
\hline \multirow{3}{*}{$\begin{array}{l}\text { PSB } \\
\text { (Positive symbolic } \\
\text { benefit) }\end{array}$} & $\begin{array}{l}\text { PSB1 - Obtain respect and prestige from people who are important to me } \\
\text { regarding my purchase choices. }\end{array}$ & 2.48 & 1.24 \\
\hline & PSB2 - Show to others how I am competent when carrying out my purchases. & 2.20 & 1.20 \\
\hline & $\begin{array}{l}\text { PSB3 - Incentivize other people to use online and offline channels simultaneously } \\
\text { in their purchasing processes. }\end{array}$ & 2.74 & 1.22 \\
\hline \multirow{3}{*}{$\begin{array}{l}\text { NSB } \\
\text { (Negative symbolic } \\
\text { benefit) }\end{array}$} & $\begin{array}{l}\text { NSB1 - Avoid mistaken recommendations from friends or family about the use } \\
\text { of online and offline purchasing channels. }\end{array}$ & 3.10 & 1.26 \\
\hline & $\begin{array}{l}\text { NSB2 - Avoid criticisms from people around me about the purchasing channels } \\
\text { I use. }\end{array}$ & 2.54 & 1.19 \\
\hline & NSB3 - Avoid criticisms about the way I make my purchases. & 2.56 & 1.28 \\
\hline
\end{tabular}

Source: research data.

\subsection{Data collection and analysis procedure}

Self-applied printed questionnaires were applied in the cities of Goiânia and Brasília, as well as online questionnaires, in a period that ran for 10 weeks. The data were inserted into an electronic spreadsheet and into the ADANCO software for Partial Least Squares (PLS) Modeling with a structure of composites - formative.

In the analysis of the assumptions, notably in the univariate and multivariate normality analyses (Mardia Index), it can be inferred that most of the asymmetry and kurtosis values were different to zero (below 1.0), approaching acceptable values; however, univariate values of the kurtosis were found that were above 1.0.
The results also indicated the non-multivariate normality of the data with a critical ratio of 6.315, and so, Partial Least Squares Modeling was used.

It should be noted that the total sample was randomly subdivided into two to evaluate the stability of the model (Cohen, 1988) for validation and calibration test purposes. However, due to limited space in the article, only the result for the total sample will be shown. Based on this, convergent validity, discriminant, and composite reliability tests were made viable (Byrne, 2010; Hair et al., 2010), as well as a confirmatory factor analysis for the process of purifying the proposed scale (Churchill, 1979). 


\section{Results}

Initially, the results from the confirmatory validations of CCB and CCB Benefits will be demonstrated. Then the CCB path analysis for the factors of the CCB Benefits is explained.

\section{I Validation of the CCB and CCB benefits scales}

Initially, Explanatory Factor Analysis (EFA) was carried out to identify the number of factors required for the explanation of $\mathrm{CCB}$ and of the CCB benefits. With the direct Oblimin method of extraction into main rotation components and Kaiser normalization, the KMO (Kaiser-Meyer-Olkin) test presented a value of 0.722 ( $\mathrm{p} \leq 0.01$ ) for CCB and 0.848 ( $\mathrm{p} \leq 0.01$ ) for the CCB benefits. The test showed that the factor analysis can be considered acceptable for the data and so the matrix could be factored.

Next, the Confirmatory Factor Analysis (CFA) was carried out for the empirical validation of the scales. The total sample was randomly divided into two subsamples (not shown in the article due to limited space), with first order constructs. The weighted Chi-squared test $\left(\chi^{2} / \mathrm{gl}\right)$ resulted in $2.54(\mathrm{p} \leq 0.01)$, the $(\mathrm{GFI})$ quality adjustment index was in the order of 0.915 , CFI was in the order of 0.905, the RMSEA was 0.06 , and the SRMR was 0.05. The model was considered very good since the results found are consistent with the acceptable values of Absolute Adjustment and Parsimonious Adjustment (Byrne, 2010; Hair et al., 2010).

The final convergent validity test (upper part of Table 2) indicated that the loads of the first order constructs are significant and that there is evidence that the observable variables have convergent validity. All the constructs confirmed by the CFA had an Average Variance Extracted (AVE) of more than 0.50.

The composite reliability test showed that all the variables that remained in the measurement model of each construct had more than 0.70 reliability, with the minimum reliability resulting in 0.75 and the maximum in 0.91 . The Cronbach's alpha was higher than 0.70. All these values indicate that the constructs and observable variables confirmed by the CFA are reliable and represent the constructs well, in accordance with the indications of Hair et al. (2010).

The discriminant validity (DV) analysis occurred using the Fornell and Larcker criterion and can be seen in the lower part of Table 2. The result shows that the AVE value of the constructs was greater than the value of the correlations squared (Hair, Gabriel, \& Patel, 2014). The constructs are different and do not overlap each other, thus presenting discriminant validity.

Table 2

\section{Convergent Validity (AE), Composite Reliability (CR), and Discriminant Validity of the first} order factors

\begin{tabular}{|c|c|c|c|c|c|c|c|}
\hline Convergent Validity & Comp. & Search & Inter. & PSB & NSB & PUB & NUB \\
\hline CCB1 & 0.65 & & & & & & \\
\hline СCB2 & 0.76 & & & & & & \\
\hline CCB3 & 0.71 & & & & & & \\
\hline ССB 4 & & 0.86 & & & & & \\
\hline CCB5 & & 0.84 & & & & & \\
\hline ССB6 & & 0.76 & & & & & \\
\hline CCB7 & & & 0.77 & & & & \\
\hline CCB8 & & & 0.80 & & & & \\
\hline ССB9 & & & 0.61 & & & & \\
\hline PSB1 & & & & 0.87 & & & \\
\hline
\end{tabular}




\begin{tabular}{|c|c|c|c|c|c|c|c|}
\hline PSB2 & & & & 0.83 & & & \\
\hline PSB3 & & & & 0.82 & & & \\
\hline NSB1 & & & & & 0.75 & & \\
\hline NSB2 & & & & & 0.93 & & \\
\hline NSB3 & & & & & 0.92 & & \\
\hline PUB1 & & & & & & 0.79 & \\
\hline PUB2 & & & & & & 0.74 & \\
\hline PUB3 & & & & & & 0.82 & \\
\hline NUB1 & & & & & & & 0.76 \\
\hline NUB2 & & & & & & & 0.81 \\
\hline NUB3 & & & & & & & 0.80 \\
\hline AVE & 0.51 & 0.67 & 0.54 & 0.71 & 0.76 & 0.62 & 0.63 \\
\hline $\mathrm{CC}$ & 0.75 & 0.86 & 0.78 & 0.88 & 0.91 & 0.83 & 0.84 \\
\hline Discriminant Validity* & Comp. & Search & Inter. & PSB & NSB & PUB & NUB \\
\hline Comparison & 0.51 & 0.25 & 0.16 & & & & \\
\hline Search & & 0.67 & 0.13 & & & & \\
\hline Interaction & & & 0.54 & & & & \\
\hline PSB & & & & 0.71 & 0.19 & 0.03 & \\
\hline NSB & & & & & 0.76 & 0.06 & 0.05 \\
\hline PUB & & & & & & 0.62 & 0.27 \\
\hline NUB & & & & & & & 0.63 \\
\hline
\end{tabular}

*Note: Numbers in the main diagonal refer to the average variance extracted - AVE and numbers outside the diagonal are the values of the correlations between the constructs of the model squared (Fornell \& Larcker, 1981).

Key: Comp. (comparison of products/prices), Search (simultaneous search for information), Inter. (interaction with retailer/ manufacturer), PSB (positive symbolic benefits of CCB), NSB (negative symbolic benefits of CCB), PUB (positive utilitarian benefits of CCB), NUB (negative utilitarian benefits of CCB).

\subsection{Structural model of CCB and its benefits}

Initially, tests were carried out to determine the reflexive or formative structure of the second and third order constructs using Partial Least Squares (Gudergan, Ringle, Wende, \& Will, 2008). The tetrad analyses proved that both the CCB and Benefits second order constructs and the Benefits third order one obey a formative structure $(\mathrm{p} \leq 0.01)$. Thus, the structural model with the first order CCB factors was pursued, forming its second order factor, and three formats of relationships with the benefits were tested, containing: (1) only the third order factor, (2) only the second order factors, and (3) only the first order factors. This was necessary due to the formative structure of the CCB benefits.

All these tests obtained good adjustment indicators for the estimated model (SRMR 0.02; $\mathrm{d}_{\text {uls }}=0.01 ; \mathrm{d}_{\mathrm{g}}=0.01$, all below the corresponding value of the $99 \%$ percentile - HI99 - and 95\% percentile - HI95\%), thus being better for the third order model of the benefits. The results can be seen in Table 3 . 
Table 3

Total standardized estimates of the direct and hierarchically mediated relationships of the Structural Model

\begin{tabular}{lccccccc}
\hline & \multicolumn{9}{c}{ Dependent Variable } \\
\cline { 2 - 8 } $\begin{array}{l}\text { Independent } \\
\text { Variable }\end{array}$ & $\begin{array}{c}\text { Benefits } \\
\left(\mathbf{3}^{\text {rd } \text { order })}\right.\end{array}$ & $\begin{array}{c}\text { Symbolic } \\
\text { Benefit } \\
\left(\mathbf{2}^{\text {nd }} \text { order }\right)\end{array}$ & $\begin{array}{c}\text { Utilitarian } \\
\text { Benefit } \\
\left(\mathbf{2}^{\text {nd }} \text { order }\right)\end{array}$ & $\begin{array}{c}\text { Positive } \\
\text { Symbolic } \\
\text { Benefit }\left(\mathbf{1}^{\text {st }}\right. \\
\text { order })\end{array}$ & $\begin{array}{c}\text { Negative } \\
\text { Symbolic } \\
\text { Benefit }\left(\mathbf{1}^{\text {st }}\right. \\
\text { order })\end{array}$ & $\begin{array}{c}\text { Positive } \\
\text { Utilitarian } \\
\text { Benefit } \\
\left(\mathbf{1}^{\text {st }} \text { order }\right)\end{array}$ & $\begin{array}{c}\text { Negative } \\
\text { Utilitarian } \\
\text { Benefit } \\
\left(\mathbf{1}^{\text {st }} \text { order }\right)\end{array}$ \\
\hline $\mathrm{CCB}$ & $0.42^{* *}$ & $0.29^{* *}$ & $0.29^{* *}$ & $0.21^{* *}$ & $0.28^{* *}$ & $0.19^{* *}$ & $0.31^{* *}$ \\
Interaction & $0.15^{* *}$ & $0.11^{*}$ & $0.11^{*}$ & $0.07^{*}$ & $0.10^{*}$ & $0.07^{*}$ & $0.11^{*}$ \\
Search & $0.16^{* *}$ & $0.12^{*}$ & $0.12^{*}$ & $0.09^{*}$ & $0.12^{*}$ & $0.08^{*}$ & $0.13^{*}$ \\
Comparison & $0.18^{* *}$ & $0.14^{* *}$ & $0.14^{* *}$ & $0.10^{*}$ & $0.14^{* *}$ & $0.09^{*}$ & $0.15^{* *}$ \\
\hline
\end{tabular}

${ }^{*} \mathrm{p} \leq 0.05 ;{ }^{* *} \mathrm{p} \leq 0.01$

Key: Comparison (first order factor of product/price comparison), Search (first order factor of simultaneous information search), Interaction (first order factor of interaction with retailer/manufacturer).

It is perceived that the greater the adoption of $\mathrm{CCB}$, the greater the perception of achieving Benefits $(B=0.42 ; \mathrm{p} \leq 0.01)$, predicted by all the first order constructs of CCB, especially product/price comparison ( $\mathrm{B}=0.18 ; \mathrm{p} \leq 0.01)$. It is observed that the greater the adoption of $\mathrm{CCB}$, the greater the perception of achieving the Symbolic Benefit $(\mathrm{B}=0.29 ; \mathrm{p} \leq 0.01)$ and Utilitarian Benefit $(B=0.29 ; \mathrm{p} \leq 0.01)$, predicted in a similar way for both by all the first order constructs of $\mathrm{CCB}$, especially price/product comparison ( $\mathrm{B}=0.14 ; \mathrm{p} \leq 0.01)$. And, finally, the greater the adoption of $\mathrm{CCB}$, the greater the perception of achieving all the first order benefits, especially the Negative Utilitarian Benefit ( $\mathrm{B}=$ $0.31 ; \mathrm{p} \leq 0.01)$ and the Negative Symbolic Benefit
$(B=0.28 ; p \leq 0.01)$. All were predicted by the first order factor of CCB, especially price/product comparison (varying from $\mathrm{B}=0.09$ to 0.15 ).

Figure 2 illustrates the path analysis of the final structural model of the first, second, and third order factors with the standardized weights on the axes that form the greater hierarchical structure and the CCB estimate ( $2^{\text {nd }}$ order) regarding the Benefits ( $3^{\text {rd }}$ order), $0.42(\mathrm{p} \leq 0.01)$. The explained variance regarding the Benefits is in the order of $18 \%$, which means that CCB is responsible for a low alteration in the performance of the consumer purchasing process, indicating that there are other explanatory variables for this performance that are not investigated in this study. 


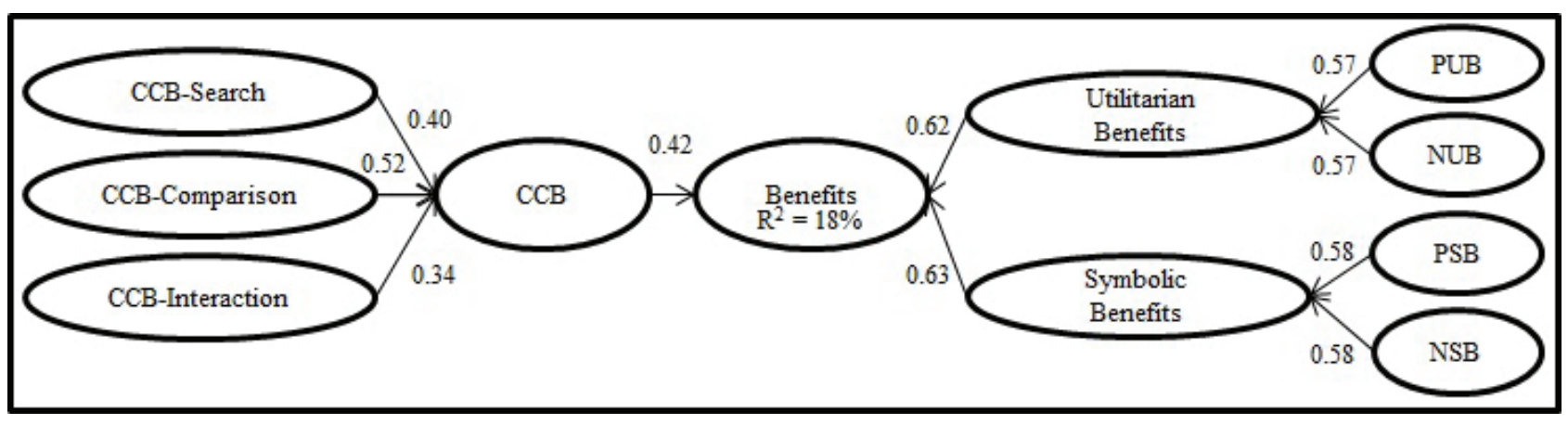

Figure 2. Path analysis of the final structural model.

Obs: All the relationships are significant $(\mathrm{p} \leq 0.01)$.

Key: PSB (positive symbolic benefits of CCB), NSB (negative symbolic benefits of CCB), PUB (positive utilitarian benefits of CCB), NUB (negative utilitarian benefits of CCB), Benefits (benefits of CCB), Symbolic Benefits (symbolic benefits of CCB), Utilitarian Benefits (utilitarian benefits of CCB), CCB (Cross Channel Behavior), Comparison (product/price comparison), Search (simultaneous information search), Interaction (interaction with the retailer/manufacturer).

\section{Discussion}

The results demonstrate that by often adopting Cross Channel Behavior, the consumer perceives the obtainment of benefits related to it. These benefits are gains and the avoidance of utilitarian and symbolic losses, which can improve the consumer's performance, making the process of purchasing products/services more agile and efficient. This finding corroborates with the studies on auxiliary precurrent behaviors in the behavioral literature (Dias \& Oliveira-Castro, 2006; Oliveira-Castro, 2003; Oliveira-Castro \& Campos, 2004; Pohl \& Oliveira-Castro, 2008) and also the use of purchasing multi-channels (Trenz, 2015), indicating that common consumer behaviors, when the online and offline channels are used, can make the purchasing process more efficient (e.g. finding better quality products, saving time and resources, etc).

Thus, by adopting CCB, consumers obtain gains (they choose products that provide better quality, they verify the availability of products, they receive compliments, etc) and avoid costs or risks (they save time and resources, they avoid delays and criticism, etc). This induces the obtainment of reinforcers (Foxall, 1998, 2005, and 2010) that can stimulate the repetition of
CCB for a better purchasing process (Gensler et al., 2012).

Oliveira-Castro and Campos (2004) already reported that when the individual presents good performance, he engages in behaviors (e.g. buying) as a result of the training from auxiliary precurrent responses (searching for information, comparing prices, etc), but after some time he no longer trains (he eliminates the auxiliary precurrent behavior) because he has already learned (he has learned what product/service to buy and how to buy it).

Thus, the availability of new (online) purchasing technologies enables new procedures to be learned regarding how to buy products/ services (Gensler et al., 2012; Gerritsen et. al., 2014). This requires the consumer to test this new technology or these new technologies (Xu et al., 2010) and learn new behaviors in relation to the previously learned purchasing process. The results of this study show that consumers are learning to improve their purchasing processes by simultaneously using the online and offline channel, since on a scale of 1 to 5 , the consumers adopt CCB with a general average of 3.5 (Standard Deviation $=0.7$ )

Therefore, the result of this study indicates that the CCB auxiliary precurrent behaviors come 
to exist and are useful for the consumer to learn to buy "better". This is shown by this study in the relationship between the CCB second order factor and the CCB Benefits third order factor. Thus, behaviors of searching for stores, simulating purchases, clicking on search fields on web pages, and accessing Customer Services are behaviors produced by consumers that are shown to be part of the way information is searched for, products or prices are compared, and the interaction takes place with retailers/manufacturers (validated here as CCB Scale constructs) to obtain gains or minimize losses. The CCB dimensions found here are new behaviors involving adaptation to new technologies (Xu et al., 2010) that show new ways of doing old "things". That is, they are new purchasing procedure behaviors to obtain more reinforcers and reduce punishers (Foxall, 2010).

In turn, there are two types of CCB Benefits (utilitarian and symbolic) that can be subdivided into positive and negative. $\mathrm{CCB}$ exerts a similar influence over utilitarian and symbolic benefits, mainly derived from product/price comparison, corroborating studies from Foxall $(2005,2010)$ and the model in this study, inspired by the Behavioral Perspective Model.

However, this study specifically demonstrates that the positive and negative dimensions of both benefits are predicted by CCB. These positive and negative benefits are ways of achieving reinforcers and avoiding punishers (Moreira \& Medeiros, 2009). In particular, the Negative Utilitarian and Symbolic Benefits are the types of benefits best predicted by CCB, indicating that the postponement of payments, avoidance of delays in obtaining a product, and avoidance of criticism from close ones are the main reinforcers. This result indicates that by using CCB in their purchasing processes, consumers mostly respond to the stimuli of removal or reduction of both utilitarian and symbolic aversive events.

Thus, the high frequency of adoption of CCB produces an attempt (training) to improve the consumer's performance with regard to his/her purchasing process. Together, the CCB Benefits are qualified as consequences that improve purchasing processes and this study presents a statistically validated scale to determine this process.

\section{Final Remarks}

This paper has developed and validated a scale of adoption of cross channel behavior and its utilitarian and symbolic benefits, these being both positive and negative. The multidimensionality of CCB (simultaneous information search, product/ price comparisons, and interaction with retailers/ manufacturers) and of the CCB benefits enabled good adjustment parameters to be acquired and parsimony of the final structural model of the research. The finding of the relationship between the constructs enabled an improvement in the performance of the consumer's purchasing process to be determined, especially the avoidance of costs and losses.

Despite the validated scale covering a broad spectrum of cross channel behaviors, not all were addressed, thus constituting a limitation of the study. As they are dynamic, new online and offline behaviors can emerge and alter the purchasing process, and this can lead to updates of the validated scale. Similarly, the benefits investigated here were related to the purchasing process, and CCB may generate other types of benefits. Future studies could address them and carry out experimental studies with (or without) the CCB scale and its perceived benefits, determining reinforcers and punishers in a longitudinal study.

The practical implications of the paper relate to the detection of the performance of the consumer's purchasing process. Marketing consultants can use the validated scale to diagnose the possibilities or not of implementing integrated management of the online and offline channels of a particular company. For example, detecting the intended strategy assists in obtaining gains for the consumer (better quality of products) derived from the consumer's purchasing process. Marketing researchers can use the CCB scale and 
that of its benefits to advance knowledge regarding the sales process in different retail channels and the consumer purchasing process. All in all, the study contributes by offering a measure that determines the consumer's performance in his/ her modern purchasing process.

\section{References}

Aghekyan-Simonian, M., Forsythe, S., Kwon, W. S., \& Chattaraman, V. (2012). The role of product brand image and online store image on perceived risks and online purchase intentions for apparel. Journal of Retailing and Consumer Services, 19(3), 325-331.

Arnold, M. J., \& Reynolds, K. E. (2003). Hedonic shopping motivations. Journal of Retailing, 79(3), 77-95.

Bhatnagar, A., \& Ghose, S. (2004). A latent class segmentation analysis of E-shoppers. Journal of Business Research, 57(7), 758-767.

Bell, D. R., Choi, J., \& Lodish, L. (2012). What matters most in internet retailing. MIT Sloan Management Review, 54(1), 27.

Byrne, B. M. (2010). Structural equation modeling with AMOS: Basic concepts, applications, and programming (2nd. Edition) New York: Routledge.

Bramall, C., Schoefer, K., \& Mckechnie, S. (2004). The determinants and consequences of consumer trust in E-retailing: A conceptual framework. Irish Marketing Review, 17(1-2), $13-22$.

Bridges, E., \& Florsheim, R. (2008). Hedonic and utilitarian shopping goals: The online experience. Journal of Business Research, 61(4), 309-314.

Campbell, C. (2001). Ética romântica e o espirito do consumismo moderno. Rio de Janeiro: Rocco, 2001.

Cheong, J. H., \& Park, M. (2005) Mobile Internet acceptance in Korea, Internet Research,
15(2), 125-140.

Churchill, G.A. (1979). A paradigm for developing better measures of marketing construts. Journal of Marketing Research, 16 (1), 64-73.

Cohen, Jacob (1988). Statistical power analysis for the behavioral sciences. (2 ed), Hillsdale, NJ: Lawrence Erlbaum Associates.

Currás-Pérez, R., \& Sánchez-García, I. (2012) Satisfaction and loyalty to a website: The moderating effect of perceived risk. Esic Market Economic and Business Journal, 141, 183- 207.

Saad, R. (2013). Os poderosos do varejo global: sem fronteiras em um ambiente multicanal. Retrieved on June $20^{\text {th }}$ of 2017 from http://www2.deloitte. $\mathrm{com} /$ content/dam/Deloitte/br/Documents/consumerbusiness/PVG_2013.pdf

DeVellis, R. F. (2011). Scale development: Theory and applications (3rd ed.). Thousand Oaks, CA: Sage Publications.

Diamantopoulos, A., Riefler, P., \& Roth, K. P. (2008). Advancing formative measurement models. Journal of Business Research, 61(12), 1203-1218.

Dias, M. B., \& Oliveira-Castro, J. M. (2006). Comportamento de procura por produtos: Efeitos da quantidade de marcas. Revista Psicologia Organizaçôes e Trabalho, 6(1), 195-232.

Filomeno, J. G. B. (2011). Actualidade do direito do consumidor no Brasil: 20 anos do código de defesa do consumidor, conquistas e novos desafios. Cognitio Juris, 1(1), 11-39.

Flavián, C., Gurrea, R., \& Orús, C. (2016). Choice confidence in the webrooming purchase process: The impact of online positive reviews and the motivation to touch. Journal of Consumer Behaviour.

Fornell, C., \& Larcker, D. F. (1981). Structural Equation Models with unobservable variables and 
measurement error: Algebra and statistics. Journal of Marketing Research, 18(3), 382-388.

Foxall, G. R. (1998). Radical behaviorist interpretation: generating and evaluating an account of consumer behavior. The Behavior Analyst, 21(2), 321-354.

Foxall, G. R. (2005). Understanding consumer choice. Basingstoke: Palgrave MacMillan.

Foxall, G. R. (2010). Theoretical and conceptual advances in consumer behavior analysis: Invitation to consumer behavior analysis. Journal of Organizational Behavior Management, 30(2), 92-109.

Frazer M., \& Stiehler, B. E. (2014). Omnichannel retailing: The merging of the online and off-line environment. Global Conference on Business \& Finance Proceedings, 9(1), 655-657.

Gensler, S., Verhoef, P. C., \& Böhm, M. (2012). Understanding consumers' multichannel choices across the different stages of the buying process. Marketing Letters, 23(4), 987-1003.

Gerrtsen B. H. M., Solberg, K., Visser, P., Hoogreef, P. J. M., Hustl K., Janssen, K. H. M. L., Horselenberg L., Van Dijk, R.R., \& Consenheim, E. (2014). Social media coming to the mall: A cross-channel response. In: D. Schaefer (ed.), Product development in the socio-sphere (pp. 169235). New York: Springer International.

Giordano, T. A. (1996). O departamento de serviço ao consumidor: Sua importância, características e efeitos. São Paulo: Fundação Getúlio Vargas.

Gudergan, S. P., Ringle, C. M., Wende, S., \& Will, A. (2008). Confirmatory tetrad analysis in PLS path modeling. Journal of Business Research, 61(12), 1238-1249.

Gursoy, D., Spangenberg, E. R., \& Rutherford, D. G. (2006). The hedonic and utilitarian dimensions of attendees attitudes toward festivals. Journal of Hospitality \& Tourism Research, 30 (3), 279-294.
Hair, J. F., Black, W. C., Babin, B. J., \& Anderson, R. E. (2010). Multivariate data analysis (7th Edition). NJ: Prentice Hall.

Hair, J. F., Gabriel, M. L. D. S., \& Patel, V. K. (2014). Modelagem de equaçóes estruturais baseada em covariância (cb-sem) com o Amos: Orientações sobre a sua aplicação como uma ferramenta de pesquisa de marketing. Revista Brasileira de Marketing, - Edição Especial 13(2), 44-55.

Henseler, J., Hubona, G., \& Ray, P. A. (2016). Using PLS path modeling in new technology research: updated guidelines. Industrial Management \& Data Systems, 116(1), 2-20.

Hirschman, E. C., \& Holbrook, M. B. (1982). Hedonic consumption: Emerging concepts, methods and propositions. Journal of Marketing, 46(3), 92-101.

Holbrook, M. B. (2001). The millennial consumer in the texts of our times: Exhibitionism. Journal of Macromarketing, 21(1), 81-95.

Kim, K., \& Kim, E. (2006). Suggestions to enhance the cyber store customers' satisfaction. The Journal of American Academy of Business, 9(1), 233-240.

Kiseol, Y. (2010). Determinants of US consumer mobile shopping services adoption: Implications for designing mobile shopping services. Journal of Consumer Marketing, 27(3), 262-270.

Ling, K. C., Daud, D., Piew, T. H., Keoy, K. H., \& Hassan, P. (2011). Perceived risk, perceived technology, online trust for the online purchase intention in Malaysia. International Journal of Business \& Management, 6(6), 167-182.

Lu, H.-P., \& Su, P. Y.-J. (2009). Factors affecting purchase intention on mobile shopping web sites. Internet Research, 19 (4), 442 - 458.

Magoon, M. A., Critchfield, T. S., Merrill, D., Newland, M. C., \& Schneider, W. J. (2017). Are 
positive and negative reinforcement "different"? Insights from a free-operant differential outcomes effect. Journal of the Experimental Analysis of Behavior, 107(1), 39-64.

Moon, B. J. (2004). Consumer adoption of the internet as an information search and product purchase channel: Some research hypotheses. International Journal of Internet Marketing and Advertising, 1(1), 104-118.

Moreira, M. B., \& Medeiros, C. A. (2009). Princípios básicos de análise do comportamento. Porto Alegre: Artmed Editora.

Nagle, T. T., Hogan, J. E., \& Zale, J. (2011). The strategy and tactics of pricing (5a Ed.). New Jersey: Prentice Hall.

Neslin, S., \& Shankar, V. (2009). Key issues in multi-channel customer management: Current knowledge and future directions. Journal of Interactive Marketing, 23(1), 70-81.

Nevin, J. A., \& Mandell, C. (2017). Comparing positive and negative reinforcement: A fantasy experiment. Journal of the Experimental Analysis of Behavior, 107(1), 34-38.

O'Shaughnessy, J., \& O'Shaughnessy, N. J. (2007). Reply to criticisms of marketing, the consumer society and hedonism. European Journal of Marketing, 41 (1/2), 7-16.

Oliveira-Castro, J. M. (2003). Effects of base price upon search behavior of consumers in a supermarket: An operant analysis. Journal of Economic Psychology, 24(5), 637-652.

Oliveira-Castro, J. M., \& Campos, A. P. M. D. (2004). Comportamento precorrente auxiliar: Efeitos do número de dimensôes discriminativas da tarefa. Psicologia: Teoria e Pesquisa, 20(2), 191-199.

Oliveira-Castro, J. M., Faria, J. B., Dias, M. B., \& Coelho, D. S. (2002). Effects of task complexity on learning to skip steps: An operant analysis. Behavioural Processes, 59(2), 101-120.

Overby, J. W., \& Lee, E. J. (2006). The effects of utilitarian and hedonic online shopping value on consumer preference and intentions. Journal of Business Research, 59(10-11), 1160-1166.

Pasquali, L. (2007). Validade dos testes psicológicos: Será possível reencontrar o caminho? Psicologia: Teoria e Pesquisa, 23 (Special Edition), 99-107.

Pauwels, K, Leeflang, P.S. H., Teerling ML., \& Huizingh, K.R.E. (2011) Does online information drive offline revenues? Only for specific products and consumer segments! Journal of Retailing, 87(1), 1-17.

Pohl, R., \& Oliveira-Castro, J. (2008). Efeitos do nível de benefício informativo das marcas sobre a duração do comportamento de procura. Revista da Administração Contemporânea Eletrônica, 2(3), 449-469.

Raghunathan, R., \& Corfman, K. (2006). Is happiness shared doubled and sadness shared halved? Social influence on enjoyment of hedonic experiences. Journal of Marketing Research, 43(3), 386-394.

Rigby, D. (2011). The future of shopping. Harvard Business Review, 89(12), 65-76.

Shin, D. (2009). The evaluation of user experience of the virtual world in relation to extrinsic and intrinsic motivation. International Journal of Human-Computer Interaction, 25(6), 530.

Skinner, B. F. (1969). Contingencies of reinforcement: $A$ theoretical analysis. Englewood Cliffs, NJ: Prentice-Hall.

Srivastava, J., \& Chakravarti, D. (2011). Price presentation effects in purchases involving tradeins. Journal of Marketing Research, 48(5), 910-919.

Trenz, M. (2015). Multichannel commerce: $A$ consumer perspective on the integration of physical 
and electronic channels. New York: Springer International.

Valentini, S., Montaguti, E., \& Neslin, S. (2011). Decision process evolution in customer channel choice. Journal of Marketing, 75(11), 72-86.

Van Riel, A. C., Henseler, J., Kemény, I., \& Sasovova, Z. (2017). Estimating hierarchical constructs using consistent partial least squares: The case of second-order composites of common factors. Industrial Management \& Data Systems, $117(3), 459-477$.

Xu, X., Venkatesh, V., Tam, K. Y., \& Hong, S. J. (2010). Model of migration and use of platforms: Role of hierarchy, current generation, and complementarities in consumer settings. Management Science, 56(8), 1304-1323.

Zang, A.Y. (2012). Evidence on the trade-off between real activities manipulation and accrual based earnings management. The Accounting Review, 87(2), 675-703.

Zhou, W. Tu., \& Piramuthu, S. (2010) RFIDenabled item-level retail pricing. Decision Support Systems, 48(1), 169-179.

\section{Note}

1 A preliminary version of this article titled "Construção e Validação da Escala de Comportamento Cross Channel de Compra e de Seus Benefícios ao Consumidor" was presented at the Enanpad meeting on September $25^{\text {th }}-28^{\text {th }}$ of 2016 at the Costa do Sauípe.

\section{Supporting Agencies:}

CAPES - Coordination for the Improvement of Higher Education Personnel - MEC

About the Authors:

1. Rafael Barreiros Porto, Post-Doctor in Business, University of Brasilia, Brasilia, Brazil. E-mail: rafaelporto@unb.br

\section{ORCIID}

(iD) 0000-0003-2210-7098

2. Sionara Ioco Okada, Phd in Marketing, University of Brasília, Brasilia, Brazil.

Email: sionara14@gmail.com

ORCIID

(iD) 0000-0002-3953-0629

\section{Contribution of each author:}

\begin{tabular}{lcc}
\hline Contribution & Rafael Barreiros Porto & Sionara Ioco Okada \\
\hline 1. Definition of research problem & $\sqrt{ }$ & $\sqrt{ }$ \\
2. Development of hypotheses or research questions (empirical studies) & $\sqrt{ }$ & $\sqrt{ }$ \\
3. Development of theoretical propositions (theoretical work) & $\sqrt{ }$ \\
4. Theoretical foundation/Literature review & $\sqrt{ }$ \\
5. Definition of methodological procedures & & $\sqrt{ }$ \\
6. Data collection & $\sqrt{ }$ \\
7. Statistical analysis & $\sqrt{ }$ \\
8. Analysis and interpretation of data & $\sqrt{ }$ \\
9. Critical revision of the manuscript & $\sqrt{ }$ \\
10. Manuscript writing & $\sqrt{ }$ \\
\hline
\end{tabular}

